\title{
IMPROVING THE CRITERIA FOR DETERMINING DATES OF REPAIR OF HIGHWAYS
}

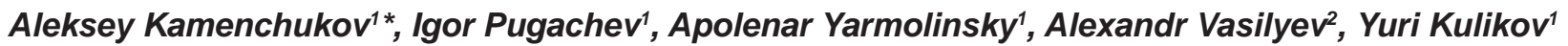 \\ ${ }^{1}$ Pacific National University \\ ${ }^{2}$ Far Eastern State Transport University
}

The article is devoted to the improvement of criteria for determining highways iterrepair periods. The authors reveal the importance of technical and operating characteristics, vehicle operating status and techno-economic parameters of roads. Analyzes the existing assessing the quality criteria of state highways that affect their compliance with consumer properties. The possible main criteria that determine the necessary composition and periodicity of carrying out of major repairs of roads of different categories and in different climatic zones.

Key words: Overhaul period, The failure of the road structure, Residual resource, Technical and operational qualities of roads.

\section{INTRODUCTION}

Currently, the number of vehicles carrying heavy cargo in the volume of traffic flow is steadily increasing.

Due to these circumstances, the Government of the Russian Federation has introduced the rules for compensation of the damage caused by the vehicles carrying heavy cargo (Government of the Russian Federation 2009).

In this regard, a more detailed study of the impact of such vehicles on the road pavement, and the determination of the damage to the road condition and the intermaintenance period clarification are required. This issue is actively discussed in scientific journals (Popov 2013; Gokhman 2015).
The study of the principles of establishing the dates of major repairs

Rosavtodor is also conducting systematic work on this issue. Thus, the problems of updating the statutory framework are being resolved. In 2016, the "Methodological recommendations on increasing life duration of non-rigid road pavements" were approved(Bakhrakh 2014; Rosavtodor 2015).

Currently, GEO-PROJECT LLC is developing some recommendations for determining the damage caused by the vehicles having an authorized maximum mass exceeding 12 tons.

Table 1: The inter-maintenance period of capital repairs of public federal significance non-rigid road pavements

\begin{tabular}{|c|c|c|c|c|c|c|c|}
\hline \multirow{3}{*}{$\begin{array}{l}\text { Road } \\
\text { category }\end{array}$} & \multirow{3}{*}{$\begin{array}{c}\text { Type of } \\
\text { pavement }\end{array}$} & \multicolumn{6}{|c|}{ Road climatic zone } \\
\hline & & \multicolumn{2}{|c|}{ I- II } & \multicolumn{2}{|c|}{ III } & \multicolumn{2}{|c|}{ IV-V } \\
\hline & & $\begin{array}{c}\text { Inter- } \\
\text { maintenance } \\
\text { period, years }\end{array}$ & $\begin{array}{c}\text { The road } \\
\text { covering safety } \\
\text { factor }\end{array}$ & $\begin{array}{c}\text { Inter- } \\
\text { maintenance } \\
\text { period, years }\end{array}$ & $\begin{array}{c}\text { The road } \\
\text { covering safety } \\
\text { factor }\end{array}$ & $\begin{array}{c}\text { Inter- } \\
\text { maintenance } \\
\text { period, years }\end{array}$ & $\begin{array}{c}\text { The road } \\
\text { covering safety } \\
\text { factor }\end{array}$ \\
\hline IA, IB, IC & $\begin{array}{l}\text { heavy-duty } \\
\text { pavement }\end{array}$ & 12 & 0,98 & 14 & 0,95 & 18 & 0,88 \\
\hline II & $\begin{array}{l}\text { heavy-duty } \\
\text { pavement }\end{array}$ & 12 & 0,95 & 12 & 0,92 & 15 & 0,88 \\
\hline \multirow[t]{2}{*}{ III } & $\begin{array}{c}\text { heavy-duty } \\
\text { pavement }\end{array}$ & 12 & 0,92 & 12 & 0,90 & 15 & 0,85 \\
\hline & lightweight & 12 & 0,86 & 12 & 0,85 & 12 & 0,84 \\
\hline \multirow{3}{*}{ IV } & $\begin{array}{l}\text { heavy-duty } \\
\text { pavement }\end{array}$ & 12 & 0,85 & 12 & 0,84 & 12 & 0,83 \\
\hline & lightweight & 10 & 0,85 & 10 & 0,84 & 12 & 0,82 \\
\hline & transition & 5 & 0,82 & 5 & 0,80 & 5 & 0,77 \\
\hline \multirow{3}{*}{ V } & lightweight & 10 & 0,82 & 10 & 0,80 & 12 & 0,79 \\
\hline & transition & 5 & 0,65 & 5 & 0,60 & 5 & 0,58 \\
\hline & lower & 3 & 0,65 & 3 & 0,60 & 3 & 0,58 \\
\hline
\end{tabular}


These recommendations will allow assessing the appointment of the inter-maintenance period differentially depending on traffic congestion, including the transport of heavy loads.

The periodicity of the inter-maintenance period established by the current standards is given in Table 1. (Ministry of Transport 2007).

According to this table, we can conclude that the frequency of work on the overhaul with a given road covering safety factor is determined by the following parameters: category of road, type of pavement, road-climatic zone.

However, this table does not answer the following question: what are the main criteria to determine the need for roadway replacement?

If we compare, for example, a section of an IB road category in I - II the road-climatic zone (the inter-maintenance period is 12 years, the share of the movement of trucks in the traffic flow is about $70 \%$ ) with the same section in IV-V road climatic zone (the share of trucks is about $30 \%$ ), the actual pavement condition of these two sections will differ from each other significantly. Accordingly, the composition of the repair work must also have significant differences.

However, in the above table, the purpose of the repair does not take into account the condition of the roads with defects, as well as the peculiarities of the traffic flow. (Radovskiy2006; Ministry of Transport 2007).

\section{Estimation of the condition of the road before its repair}

The road condition is estimated by a number of indicators. It is necessary to distinguish the technical and operational quality of roads (TOQR), the transport and operational quality of roads (TOQR) and the technical and economic roads indicators (TEIR).

A number of parameters estimate the technical and operational qualities. These parameters include evenness, roughness and adhesion qualities of pavement, pavement strength, indicators taking into account the availability and quality of engineering equipment and arrangement (marking, guides and fencing devices, road signs, bus stops, etc.). Practically, these parameters are measured in absolute values (for example, the actual modulus of elasticity of the road structure) or in relative form (engineering equipment and arrangement ratio).

The transport and operational quality is a set of parameters to assess the operational condition of roads at the time of examination. They include the traffic capacity and the road load level of traffic, the uncongested traffic capacity, the permissible axle load, and the permissible gross mass of the carload, the accident rate and the road safety factors, and so on.

The technical and economic indicator is a set of parameters evaluating the transport and the road (on which the transportation is carried out) collaboration. They primarily include the cost of road transport, the average speed of traffic flow, the presence and concentration of road accidents, tire wear, fuel consumption, types and concentration of harmful substances emissions and so on.

All the indicators and parameters evaluating the roads are closely related. Therefore, for example, the surface roughness of pavement affects adhesion, the choice of driving speed, tire wear, road safety.

The actual road condition for having defects is determined by the results of a comprehensive diagnostics of (Rosavtodor 2002). The assessment of the transport and operational road condition is carried out according to the degree of compliance with the regulatory requirements of the main transport and operational indicators of roads, which are taken for its consumer performance (Kim, Yeo. 2017).

The main consumer performances include speed, fluidity, safety, and convenience of movement, traffic capability and, road loading level; the ability to pass cars and trucks with axle loads allowed for movement, the total weight, and dimensions, as well as environmental safety.

The result of the assessment is a generalized indicator of the quality and condition of the road (Ir) including a comprehensive indicator of the transport and operational condition of the road (Clr), an indicator of engineering equipment and arrangement (leq), and maintenance level indicator ( $\mathrm{Im})$

$$
I_{r}=C I_{r} \times I_{e q} \times I_{m}
$$

Indicators Ir, CIr, leq, Im are the criteria for assessing the quality and condition of roads.

The concept of economic efficiency criterion, which is characterized as optimal in the conditions of insufficient funding for the appointment of repairs, is also introduced in this standard.

If funding is sufficient, the value of the transport effect on the carriage of goods and passengers is considered as the criterion for assigning work priorities. If the cost of work performed is important the integral effect criterion is taken as the criterion for assigning work priorities.

Also, the need for repairs is determined by the criterion of estimated traffic speed security $\mathrm{KPClJ}$ (taking into account the intensity and type of traffic). It is compared with the normative value of the complex indicator of the transport and operational condition (Clr) and with its maximum rating values.

If funding is insufficient, the repair work planning is carried out taking into account the concentration of traffic accidents and the site loading level. It is based on the "coincidence index" criterion. This criterion evaluates traffic safety requirements taking into account its intensity. It is determined by expert means. 
This system of criteria seems cumbersome and controversial since the quality control of the road condition obtained from them does not affect the frequency of the inter-maintenance period presented in Table 1.

\section{Accounting of the volume of cargo transportation in determining the time of major repairs of roads}

Taking into account the steadily increasing traffic intensity with the growth of freight component, the most important thing is the influence of road transport on the road condition, taking into account the load weight transported through this section over a period. Actually, the main purpose of the road is to ensure that it would be guaranteed to carry a certain amount of cargo (passengers).

However, the currently used method of assessing the quality of roads and planning repairs does not allow considering these features fully, since the existing methods do not trace the main link:

\section{VOLUME OF TRANSPORTED CARGO $\Longrightarrow$ THE EFFECT OF THIS VOLUME ON ROAD CONDITION $\Longrightarrow$ ASSESSMENT OF ROAD CONDITION $\Longrightarrow$ APPOINTMENT OF A SPECIFIC REPAIR TYPE.}

The appointment of inter-maintenance periods and the types of repair work should be based on a technical and economic approach. When analyzing the effectiveness of road repair work, both operational and economic effects from the performance of road repair work should be considered.

Determining the time of repair works and their types should be aimed to achieve the maximum economic effect of the repair and, above all, to extend the service life of the road while minimizing the costs of its maintenance and repair.

One of the most important conditions for assessing the effectiveness of road repair is the expected improvement in the transport and operational pavement condition (Wickramarathne, Garg, Bauer 2018). The improvement of the pavement condition is estimated by international indicators: the flatness index IRI and the index of the current operational condition of the coating $\mathrm{PCl}$ (Berton, Bouaanani, Lamarche, Roy 2017) (fig. 1).

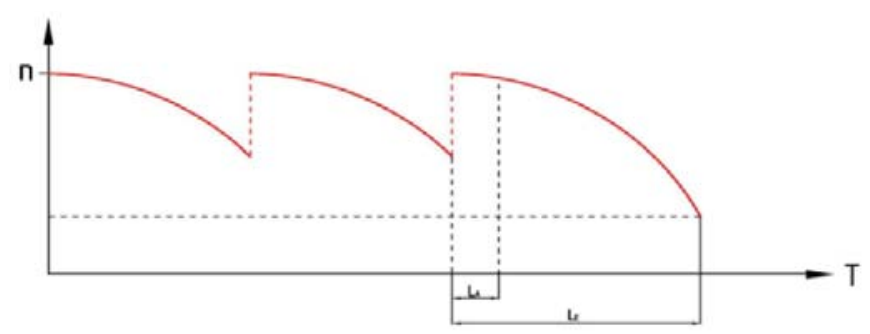

Where $\mathrm{n}$ - the index of operational road condition, $\mathrm{T}$ - durability of pavement, years.

Fig.1: The change in the index operational status of the road.

The indicators of the transport and operational pavement condition can be used to estimate the optimal repair time, the type of repair aimed at maintaining or improving the existing traffic conditions and capable of suspending the process of road pavements deformation and destruction. The improvement assessment in operational condition after repairing is necessary to change the curve of the index of the operational pavement condition and to assess how long the life of the pavement has increased. Changing the index of the operational pavement condition curve may change over time. Therefore, using the results of road diagnostics the prediction of the changes in the transport and operational pavements condition is required. (Wu, Xiang, Gong 2017; Yakimenko, Bogomolov, Morozov, Sokolova 2017).

The optimal time for the roads repair is determined on the basis of the repair efficiency index El. The optimal time for repair is characterized by minimal repair costs while achieving the maximum possible effect on improving the transport and operational road quality.

For each road pavement repair option, the road repair efficiency index $\mathrm{El}$ is determined. The maximum efficiency index is determined by cyclic comparison of efficiency indices among themselves. The efficiency index for each repair option is determined by the formula (Walls, Smith1998; Kamenchukov, YArmolinskiy, Krivko2016; Hauser, Ševelová, Matula, Zedník 2018):

$$
E I_{i}=\left[\frac{(E / C)_{i}}{(E / C)_{\max }}\right] \times 100
$$

where: Eli - efficiency index of the i-th road repair option; $(E / C)$ i- performance indicator of the work quality for the i-th option; $\mathrm{E}$ - operational effect of road repair; C - the cost of repairs, thousand rubles.

\section{Determination of costs arising during the entire service life of the road}

To determine the costs deriving during the whole road life, a model estimating how the quality of the pavement affects the costs arising throughout the road life has been developed. Costs arising during the entire service life are estimated by the indicator of the road life cycle cost. This indicator is determined by the formula

$\mathrm{LCCA}=\mathrm{MC}+\mathrm{PMC}+\mathrm{UC}-\mathrm{SV}$

where $M C$ - road maintenance costs;

PMC - road repair costs;

UC - costs incurred by road users for using the road; SV - depreciation value of pavement.

When calculating the cost of maintaining a road, it is necessary to know its category, intensity, and type of traffic, types of road maintenance work and the level of its operational condition. The total cost of maintaining a road network is determined by the formula:

$$
M C=a+b(100-P C I) \times N
$$


where $\mathrm{PCl}$ - the level of the transport and operational condition of the pavement; $a, b$ - empirical parameters determined in accordance with local conditions and work performed.

Additionally, to assess the distribution of costs, you need to know the frequency of repairs and the methods by which they are performed. Depending on the road category, pavement type, and its transport and operational condition, repair costs are calculated individually. The frequency of repairs is determined by the inter-maintenance period and the total service life of the pavement.

The cost of repairing the road network is determined by the formula:

$$
P M C=\sum_{i=1}^{n}\left(F_{i} \times C P_{i}\right)
$$

where $\mathrm{F}$ - the area of the i-th pavement repair area, $\mathrm{m} 2$; $\mathrm{CP}$ - the average cost of repair work by the i-th repair method on the pavement with an area of $\mathrm{m} 2$.

The amount of costs arising the participants of the movement using the road directly depends on the intensity and type of traffic. They can be up to $90 \%$ of the total cost of the road life cycle. These costs are determined by the formula:

$$
U C=C F L+C T C+C P C
$$

where CFL - the cost of gasoline and diesel fuel; CTC - the cost associated with tire wear; CPC - expenses for car maintenance.

The depreciation value of the pavement is determined based on the depreciation pavement life cycle, which depends on the degree of change in the hydraulic grade line of the pavement after the next repair, those from the actual transport and operational status. The depreciation life cycle for each road or roads network is predicted individually depending on the road category, type of pavement, traffic intensity and type of traffic, local climatic conditions and general trends and patterns of changes in the hydraulic grade line of the pavement taking into account all repair work.

The depreciation value of the pavement is calculated by the formula:

$$
S V=\left(1-\frac{L_{A}}{L_{E}}\right) C_{r}
$$

where LA is the time from the moment of the last repair work (years) to the considered calculation period; LE is the expected operational life cycle of the pavement from the moment of the last repair to the full development of all pavement resources (when the transport and operational condition of the pavement meets the minimum requirements); $\mathrm{Cr}$ is the cost of recent repairs.

Analysis of the road life cycle cost is calculated for the entire service life, taking into account all the work performed. Only, in this case, the forecast cost, for the considered option will be relevant and appropriate. The forecast period must be determined by the operational and economic factors. A short calculation period will not fully reflect all the trends in the pavement hydraulic grade line. When using expensive methods of repair, they will be the most inefficient, although they will ensure the maximum increase in operating performance. With overestimated service life, the total amount of accumulated deformations of the pavement and the excessive costs caused as a result of this will lead to the operational quality of the pavement before and after the production will vary from the minimum to the maximum allowable values. It will also make the choice of the most effective method of repair impractical. On the basis of materials on the trends and development of the economic situation in China, it was established that under the prevailing conditions of economic growth, the scope for calculating the cost of the road life cycle should be taken 10-12 years depending on the category of road and types of road pavement $[1,3,4]$.

The optimal life cycle is determined on the basis of the efficiency index, which is calculated on the basis of the operational efficiency of the work and the road life cycle cost throughout its life. Calculations are made for asphalt concrete pavement, with a calculation scope of 6 years. The results of the calculations are shown in Table 2.

Table 2: The calculation of the performance index

\begin{tabular}{|c|c|l|l|c||}
\hline $\begin{array}{l}\text { Life } \\
\text { cycle } \\
\text { (year) }\end{array}$ & $\begin{array}{l}\text { Economic } \\
\text { efficiency } \\
\text { of work }\end{array}$ & $\begin{array}{l}\text { Cost } \\
\text { of a } \\
\text { life } \\
\text { cycle }\end{array}$ & $\begin{array}{l}\text { Performance } \\
\text { indicator } \\
\text { (E/C) }\end{array}$ & $\begin{array}{l}\text { Efficiency } \\
\text { index (El) }\end{array}$ \\
\hline 1 & 49.7 & 55.00 & 0.90 & 45 \\
\hline 2 & 59.8 & 53.88 & 1.11 & 55 \\
\hline 3 & 99.7 & 50.85 & 1.96 & 98 \\
\hline 4 & 98.2 & 48.90 & 2.01 & 100 \\
\hline 5 & 74.1 & 47.01 & 1.58 & 78 \\
\hline 6 & 62.5 & 45.20 & 1.38 & 69 \\
\hline
\end{tabular}

Thus, by taking into account the weighted average data on the condition of the roads, it was established that the most effective period for repairing roads is 3-4 years of road operation.

\section{CONCLUSIONS}

Reasoning from this fact, the possible main criteria determining the necessary composition and frequency of capital repairs various roads categories and in different climatic zones can be according to their importance:

Pavement strength factor on the criterion of transverse elasticity is the ratio of the actual elastic modulus of the pavement to the minimum required modulus of elasticity, depending on the required pavement strength;

The capital roads are the compliance of the carrying pavements capacity with axial loads of moving vehicles: 
for roads I and II technical category $115 \mathrm{kN}$ (11.5 tf), for roads III and IV categories $100 \mathrm{kN}(10.0 \mathrm{tf})$, for roads $\mathrm{V}$ categories $60 \mathrm{kN}(6.0 \mathrm{tf})$.

The required level of reliability is the probability of failure-free operation of the road structure during the life duration;

The residual life of the road structure is the number of applications of the calculated load until the road structure reaches the boundary state;

Failure of the road structure is the state of road construction with unacceptable longitudinal and transverse roughness of the pavement, with the loss of the road structure durability;

The limiting coefficient of destruction is the ratio of the road sections length requiring repair due to the insufficient strength of the pavement to the total road length;

The density of freight traffic is a characteristic of the freight traffic intensity on the railway network $(t \times \mathrm{km} / \mathrm{km})$. It is determined by the ratio of the annual freight turnover (transport work) in ton-kilometers to the operational length of the road (network section) in kilometers.

An additional criterion is presenting defects, allowing to operate the road with calculated indicators, but requiring the performance of any repair work. During road usage, a ground-penetrating radar and laser survey is carried out to assess the condition and thickness of the pavement. If there are defects, the scan results are recorded in the form of digital models with the possibility of integrating into the design, reconstruction or road sections repair (Rosavtodor 2015; Kulikov, Y. I., Pugachev, I. N., Vasiliev A. E. 2017).

Using these criteria, it is necessary to introduce such concepts as "safe", "safety margin and reliable", "durability" and "maintainability" instead of the concept "consumer properties of the road". It will make possible to move from an abstract assignment of the inter-maintenance period to a clear planning for maintaining and repairing roads based on their life cycle.

\section{FORMATTING OF FUNDING SOURCES}

This research did not receive any specific grant from funding agencies in the public, commercial, or not-for-profit sectors.

\section{REFERENCES}

1. Bakhrakh G.S. (2014) The approach to the determination of asphalt concrete pavement life [Podkhod $k$ opredeleniyusrokasluzhbyasfal'tobetonnogopokrytiya]. Roads and bridges. proceedings. Moscow. 2014. Vol. 32/2, 250-263. (in Russian)

2. Berton, E., Bouaanani, N., Lamarche, C.-P., Roy, N. (2017) Finite element modeling of the impact of heavy vehicles on highway and pedestrian bridge decks.Procedia Engineering, 199, pp. 24512456. Retrieved from https://doi.org/10.1016/j.proeng.2017.09.383
3. Gokhman L. M. (2015) Increase maintenance periods roads [Povysheniemezhremontnykhsrokov].Car roads [Avtomobil'nyedorogi], No. 5, 2015. (in Russian).

4. Government of the Russian Federation (2009). The decree of the RF Government dated 16.11.2009 No. 934 "About compensation of the harm caused by vehicles transporting heavy cargoes on highways of the Russian Federation" (with changes and additions from 16.04.2011, 09.01.2014 and 27.12.2014.) [PostanovleniePravitel'stva RF ot 16.11.2009 g. № 934 «O vozmeshcheniivreda, prichinyaemogotransportnymisredstvami, osushchestvlyayushchimiperevozkityazhelovesnykhgruzovpoavtomobil'nymdorogamRossiyskoyFederatsii» (s izmeneniyamiidopolneniyamiot 16.04.2011 g., 09.01.2014g. i 27.12.2014 g.)].

5. Hauser, J., Ševelová, L., Matula, R., Zedník, P. (2018) Optimization of low volume road pavement design and construction.Journal of Forest Science, 64 (2), pp. 74-85. Retrieved from https://doi. org/10.17221/109/2017-JFS

6. KamenchukovA.V., YArmolinskiyV.A., KrivkoE.V. (2016). The impact of the initial information on the quality of the design construction and repair of roads [Vliyanieiskhodnoyinformatsiinakachestvoproektirovaniyastroitel'stvairemontaavtomobil'nykhdorog]. Khabarovsk.(in Russian)

7. Kim, S., Yeo, H. (2017) Evaluating link criticality of road network based on the concept of macroscopic fundamental diagram. Transportmetrica A: Transport Science, 13 (2), pp. 162-193. Retrieved from https:// doi.org/10.1080/23249935.2016.1231231

8. Kulikov, Y. I., Pugachev, I. N., Vasiliev A. E. (2017) Assessment of the capital of roads in their life cycle [].Science and technology in the road sector. Moscow. 2017. Vol. 4, 26-28. (inRussian)

9. Ministry of Transport (2007).Order of Ministry of transport from 01.11.2007 № 157 "About implementation of decree of the Government of the Russian Federation from August 23, 2007 № 539 "About the standard cash costs for the maintenance and repair of motor roads of Federal importance and rules of their calculation" (with changes and additions) [PrikazMintransaot 01.11.2007g. № 157 «O realizatsiipostanovleniyaPravitel'stvaRossiyskoyFederatsiiot 23 avgusta 2007 g. № 539 «O normativakhdenezhnykhzatratnasoderzhanieiremontavtomobil'nykhdorogfederal'nogoznacheniyaipravilakhikhrascheta» (s izmeneniyamiidopolneniyami)]. (in Russian).

10. Popov V. A. (2013) Increase turnaround time operation of highways [Uvelicheniemezhremontnykhsrokovekspluatatsiiavtomobil'nykhdorog].Science and technology in the road sector [Naukaitekhnika v dorozhnoyotrasli], No. 2, 2013. (in Russian). 
11. Radovskiy B.S. (2006) The problem of increasing the durability of pavements and methods of its solutions in the USA. Internet Laboratories, Inc., USA: Series: Road Construction Equipment, (2006), 108-119.

12. Rosavtodor (Federal Road Agency of the Russian Federation) (2002).ORR 218.0.006 (2002) Rules for diagnosis and assessment of the state of highways (instead of DDC 6-90) [ODN 218.0.006 Praviladiagnostikiiotsenkisostoyaniyaavtomobilnykhdorog (vzamen VSN 6-90)]. Moscow. (in Russian)

13. Rosavtodor (Federal Road Agency of the Russian Federation) (2015).ORR 218.2.065 (2015)Guidelines for the increase in maintenance periods of service of non-rigid pavements [ODM 218.0.065 Metodicheskierekomendatsiipouvelicheniyumezhremontnykhsrokovsluzhbynezhiostkikhdorozhnykhodezhd].Moscow. (in Russian).

14. Walls J., Smith M.R.(1998) Life Cycle Cost Analysis in Pavement Design. Interim. Technical Bulletin. Federal.(1998).
15. Wickramarathne, T., Garg, V., Bauer, P. (2018) On the use of 3-d accelerometers for road quality assessment. IEEE Vehicular Technology Conference, 2018-June, pp. 1-5. Retrieved from https://doi. org/10.1109/VTCSpring.2018.8417779

16. Wu, T., Xiang, L., Gong, J. (2017) Renewal of Road Networks Using Map-matching Technique of Trajectories.CehuiXuebao/ActaGeodaeticaetCartographicaSinica, 46 (4), pp. 507-515. Retrieved from https:// doi.org/10.11947/j.AGCS.2017.20150479

17. Yakimenko, A.A., Bogomolov, D.A., Morozov, A.E., Sokolova, A.V. (2017) Development and research of the information system for monitoring the condition of the road surface using mobile devices to optimize logistics and repair costs. ) Proceedings - 2017 International Multi-Conference on Engineering, Computer and Information Sciences, SIBIRCON 2017, article № 8109868, pp. 190-192. Retrievedfromhttps:// doi.org/10.1109/SIBIRCON.2017.8109868 